Meta

Journal des traducteurs

Translators' Journal

\title{
Translating Political Metaphors: Conflict Potential of zenci [negro] in Turkish-English
}

\section{Alev Bulut}

Volume 57, numéro 4, décembre 2012

Journalisme et traduction

Journalism and Translation

URI : https://id.erudit.org/iderudit/1021224ar

DOI : https://doi.org/10.7202/1021224ar

Aller au sommaire du numéro

Éditeur(s)

Les Presses de l’Université de Montréal

ISSN

0026-0452 (imprimé)

1492-1421 (numérique)

Découvrir la revue

Citer cet article

Bulut, A. (2012). Translating Political Metaphors: Conflict Potential of zenci [negro] in Turkish-English. Meta, 57(4), 909-923.

https://doi.org/10.7202/1021224ar

\section{Résumé de l'article}

Les métaphores politiques sont exprimées par des unités lexicales chargées de contenu politique. Dans le contexte de la traduction de textes politiques, le transfert de ces unités vers d'autres langues peut être une source de conflit en raison de leurs charges politique et idéologique. La diffusion d'entrevues politiques par l'intermédiaire d'un interprète permet d'illustrer comment le transfert linguistique des métaphores peut engendrer un conflit imputable aux décisions traductionnelles. Le présent article porte sur le transfert de telles métaphores dans le contexte d'une entrevue politique réalisée avec un interprète et qui peut se révéler une source potentielle de conflit. L'article présente d'abord le concept d'idéologie en traduction et les marqueurs idéologiques en relation avec celui de rectitude politique et de conflit vus comme des composantes idéologiques de la traduction politique. Sera abordé ensuite l'emploi du mot turc zenci [nègre], comme métaphore politique et son transfert linguistique en anglais. Le contexte et l'analyse de cet exemple de métaphore en langues source et cible, ainsi que les conclusions tirées de ce cas précis, visent à établir un futur terrain de discussions traitant de cas similaires en traduction politique du turc et de l'anglais.
Ce document est protégé par la loi sur le droit d'auteur. L’utilisation des services d'Érudit (y compris la reproduction) est assujettie à sa politique d'utilisation que vous pouvez consulter en ligne.

https://apropos.erudit.org/fr/usagers/politique-dutilisation/ 


\title{
Translating Political Metaphors: Conflict Potential of zenci [negro] in Turkish-English*
}

\author{
ALEV BULUT \\ Istanbul University, Istanbul, Turkey \\ bulut@istanbul.edu.tr
}

\begin{abstract}
RÉSUMÉ
Les métaphores politiques sont exprimées par des unités lexicales chargées de contenu politique. Dans le contexte de la traduction de textes politiques, le transfert de ces unités vers d'autres langues peut être une source de conflit en raison de leurs charges politique et idéologique. La diffusion d'entrevues politiques par l'intermédiaire d'un interprète permet d'illustrer comment le transfert linguistique des métaphores peut engendrer un conflit imputable aux décisions traductionnelles. Le présent article porte sur le transfert de telles métaphores dans le contexte d'une entrevue politique réalisée avec un interprète et qui peut se révéler une source potentielle de conflit. L'article présente d'abord le concept d'idéologie en traduction et les marqueurs idéologiques en relation avec celui de rectitude politique et de conflit vus comme des composantes idéologiques de la traduction politique. Sera abordé ensuite l'emploi du mot turc zenci [nègre], comme métaphore politique et son transfert linguistique en anglais. Le contexte et l'analyse de cet exemple de métaphore en langues source et cible, ainsi que les conclusions tirées de ce cas précis, visent à établir un futur terrain de discussions traitant de cas similaires en traduction politique du turc et de l'anglais.
\end{abstract}

\begin{abstract}
Political metaphors are expressed by lexical items with political content. Their transfer into other languages as part of political texts involves a potential of conflict due to their political and ideological load. Political interviews that are published through interpretation may be used to exemplify how transfer of source metaphors involve conflict depending on the translational decisions. This article focuses on the transfer of a political metaphor in an interpreter-mediated political interview as a source of potential conflict. The article first presents the concept of ideology in translation and markers of ideology in relation to political correctness and conflict as ideological aspects of political translation. It then focuses on zenci [negro/nigger] in Turkish as a political metaphor in transfer into English. The background for and the analysis of the sample metaphor in source and target languages, as well as the conclusions driven out of this case, aim to set the grounds for future discussions of similar cases in Turkish-English political translation.
\end{abstract}

\section{MOTS-CLÉS/KEYWORDS}

politique, métaphore politique, entrevue, conflit, idéologie politics, political metaphor, interview, conflict, ideology

\section{Introduction}

There is considerable research in Translation Studies (TS) on the aspect of conflict involved in translation/interpretation mediated political interviews with reference to ideology. Literature on translation and interpretation for the media shows us how the transfer of messages from one language into another has the potential of creating a 
conflict in terms of the political content of the materials in question. ${ }^{1}$ The translational grounds on which we can discuss the transfer of political texts gets concrete and interesting when the exemplification is focused on political language and political metaphors, in specific, as lexical items with conflict potential.

This article investigates the problem of translating political metaphors within the context of political texts in the example of a political interview undertaken by an American journalist with a Turkish political leader published in English through interpretation. The lexical item, namely the political metaphor, to be scrutinized in this work is zenci in Turkish. It can be rendered as both black or negro/nigger in English depending on the user's intention or concern of being politically correct or not. Political correctness, in this sense, is the user's ideological and political representation of himself/herself in a position or point of view to assert no discrimination of a class or a group of people in a community.

The article introduces the translation of political language with emphases on ideology, markers of conflict and ideology, political correctness and political metaphors in translation. It, then, deals with political texts as sensitive texts in terms of ideological content and develops the framework for the analysis of zenci as a political metaphor.

\section{Ideology and translation}

Ideology, in its broadest sense, is the stand one takes in life in keeping with his/her background, training and view of life. In this scope, ideology is an indispensable aspect of language use and text-production in the sense of both implicit/ unintended ideological load (speech and writing) and explicit/ intended uses that serve specific purposes and textual productions. Puurtinen specifies the ideological content of a text as either explicit/intentional (as in newspaper editorials, children's books, didactic texts) or implicit/unintended (such as the assumptions and general values entailed in any text). Embedded ideology is the unconscious reflection of ideology in a situation which reinforces the generally accepted notions and attitudes leading to "neutralising," "objectifying," "mystifying" effects in language use (Puurtinen 1998: 178-179).

All persuasive and addressive texts, such as news, political texts and advertisements can be categorized as having ideology in its explicit form since all of these text-types come under persuasive language use serving the functions of manipulating, influencing and creating/enforcing a change. Van Dijk defines ideology as something "constructed, used and changed by social actors as group members in specific, often discursive, social practices" (van Dijk 1998: 9). This view of ideology is relevant for our study since it makes the discussion of translating and interpreting as means of constructing ideologies possible through the decisions of the translators and interpreters as social actors.

Baker $(1997 ; 2006)$ discusses constraints and interpreter strategies in political interviews and interpreter-mediated events with regard to the pragmatic aspect of "contextualization" in several of her works. She states that interpreting utterances, just as translating sentences, gives clues as to the ideological positioning of participants (speaker, interviewer and interpreter) in a political interview, or in a translated text of an interview or speech undertaken without interpretation. The context of 
interpreting designates the lexical choices of the interpreter just as much as the lexical choices depend upon the context of language use.

Kuo and Nakamura (2005) list the findings of a case study in an article displaying proofs of apparent ideological attitudes in news translation. Their article analyzes the Chinese translations of a news report based on an interview with the first lady of Taiwan, Wu Shu-chen, in English. The Chinese translations that appeared in two newspapers known by their ideological opposition to the government are found to have transformations and noticeable stylistic and ideological changes. The researchers argue that the changes they analysed within the frame of Critical Discourse Analysis $(\mathrm{CDA})^{2}$ are not arbitrary in terms of translational decisions, as may have been supposed, but are rather ideologically motivated, reflecting the underlying opposing ideologies of the newspapers in question.

\section{Translating the markers of conflict and ideology}

Conflict is the negative result of an interaction in a situation depending on the interests and the balance of gains and losses of the parties in communication. Situations and relations depending on power and ideology have more conflict potential than ordinary situations, as well as the use of languge and text production and transfer in such power and ideology dominant situations. Text production and transfer (oral or written) in the ideology dominant field of politics is apt for conflict by nature. Political interviews and interviews with political content provide good examples of the conflict potential even without the transfer issue. Notions as abstract as conflict and ideology can be made more concrete with the linguistic markers that denote them.

Examples of creating or not-creating, even preventing conflicts in political interviews given or published through translation are quite a few, as mentioned above. Two interesting cases in Turkish relate to the legal processes that two Turkish novelists, Yaşar Kemal and Orhan Pamuk, winner of 2006 Nobel Prize for Literature, had to go through. Yaşar Kemal, in his explanation of the situation, accused the publishers of mistranslating and manipulating the content of his article published in Germany (Der Spiegel). ${ }^{3}$ Orhan Pamuk had referred to the Turkish translations of his text as a source of conflict leading to a lawsuit against him based on the charge(s) of "denigrating Turkish identity." He complained of mistranslation (transfer of a passive sentence as active) in the interview given in English which was translated first into German and then into Turkish. ${ }^{5}$

Such examples of real conflict could be analyzed by linguistic markers. To give a brief evaluation in this respect, the mistranslation of the sentence in the foot-note complained about by Pamuk seemed to show that the ideological load and the impact of the original words got changed in the translation process (see note 5). Linguistically speaking, the strategy of passivization employed in the source text got replaced by activation in the target text to come to display the agent/actor of the process rather than the passivized action.

"Ideological meanings are encoded in linguistic expressions" and linguistic strategies such as "passivization," "nominalization" or "pre-modified participle structures" serve ideological purposes in texts, as was analysed by Puurtinen in her work on translating linguistic markers of ideology in the context of English-Finnish trans- 
lations (Puurtinen 1998: 177-186). Passivization or transitivity is not merely defined as a simple strategy of language use or transfer when it serves the purpose of backgrounding the agent/actor of the verb/process intentionally or even unintentionally.

To summarize from Puurtinen, the same thing is true for the use of "nominalizations" or "pre-modified nominals" that "obscure agency, responsibility, causality by deleting the participants or giving them a peripheral role" and thus transform "processes" into "states" or "pre-accepted facts" of generally accepted notions and attitudes of common sense with no room for objection (Puurtinen 1998: 180-184).

CDA and contextualization are macro-linguistic tools used in the analysis of context based aspects of political texts as representations of their ideological content. Abstract notions such as sensitivity and ideology of political texts, as manipulational tools, can also be concretized by means of contextual/discursive indicators of this power.

\section{Political texts}

What makes a text political is its context and the use of persuasive and addressive language function in its production as an item of discourse. Political texts include spoken text-types such as speeches, addresses and interviews as well as written texttypes such as news, columns, reports and written forms of declarations, releases and reports. Political text, as Schäffner points out in her articles, is

[a]n umbrella term covering a variety of text-types or genres. Political texts fulfill different functions owing to different political activities, both in intra-state and inter-state discourse. In translation, the function of the target text may remain the same as the one of the source text (ST), or it may change [...]. (Schäffner 1997a: 132; 1997b: 119)

The social dimension of a political text is its addressiveness, the impact it creates on the listeners or readers, which in turn creates the ethical dimension of political communication, ideological manipulation and the exercise of power through words. Likewise, for instance, an interesting case of comparative discursive analysis on changing political discourses of two political leaders in Russia, L. Brejnev and M. Gorbatchev, is based on the socio-political changes in the country before and after the 1980s (Robin 1998: 2-12).

Van Dijk's critical discourse based approach to news texts seems to be applicable to political texts as well, considering the similarity of the sociocognitive dimensions of production involved (van Dijk 1988a: 2). Textual and contextual dimensions of his approach had an influence on TS scholars' treatment of media translation and the translation of political texts. To refer to van Dijk again, one can consider "contextualization" as a pre-requisite of critical research, basing "objectivity" on the pre-acceptance of "subjectivity":

We have been trained to believe that scientific inquiry, just like news reporting, should be objective, non-partisan, and disinterested. We have become accustomed to ignore its inherent contextual embedding, that is, its ultimate motivation, goals, and functions. However, if critical research has taught us one thing, it is to recognize such normative rules as characteristic instances of dominant ideology whose function is to conceal the subjective, the political [...]. (van Dijk 1988b: 289) 
To relate all the above to the world of politics and interpreting; the ethical responsibility of media correspondents in the rendering of foreign news seem to overlap with that of the interpreters' in the sense that both help build public consciousness about the world politics. We might draw some insights from a work on the importance of linguistic background and the cultural training of foreign correspondents to establish parallels with the quality and training of foreign news editors and translators/interpreters in general:

Leading newspapers and magazines around the country (USA) would be well advised to devote additional resources to the training of their reporters before sending them to the field... Foreign service officers usually receive this training at the Foreign Service Institute, with substantive seminars and language classes: journalists too, but also editors and even headline writers could use such training from a Foreign Press Institute [...] (Serfaty 1991: 236-237)

Dadge studies the bullying of reporters, the manoeuvers to isolate and limit critical reporting, the manipulation of the media environment, the engineering of public perception and undermining of any counter-narrative that could challenge the administration's story line in the process of Gulf War II. The process is analyzed from the perspective of the media's ideological and biased rendering of foreign policies and news with an account of how media coverage and lack of criticism against the administration led to the Gulf War II, that is, the invasion of Iraq in 2003. Dadge also states that, according to a report titled "Iraq on the Record: The Bush Administration's Public Statements on Iraq," that the number of misstatements/misleading statements in the media by US administration, President Bush and others, is as high as 237 (Dadge 2006: 18).

The misstatements, as they are called above, shape-up the public opinion on very critical political matters and become "accomplices in crime" unless they get filtered by the editors and translators or transeditors ${ }^{6}$ in the media. Translators and interpreters of political texts are in a conflicting situation in terms of professional ethics, especially in the case of world-wide television-broadcasting of misstatements: they are expected to translate the facts/the reality, yet, it is through them that the misstatements are broadcasted all around the world. This is a problematic topic to deal with in the field of translation as part of ethics and professionalism. "Everyone is entitled to his own opinion but not to his own facts" said US Senator Daniel Patrick Moynihan in an address (quoted in Serfaty 1991: 143). This statement may raise interesting questions in news translation and interpreting context.

\section{Political metaphors and translation: white and black}

Politics is the art and profession of persuasion. It aims at, in the final stage, manipulation of the public opinion for a chance to govern a country, ideally through a democratic electional system. Politics operates through language, that is, oral and written texts, produced in the field of politics.

A political metaphor is a lexeme or a phrase with political content and connotations. What makes a lexeme political is its use with reference to politics either as part of a political text or in a political context. Political metaphors pose constraints in translation especially in situations such as translation of political texts where a lexical choice goes through conscious or sub-conscious ideological transfer. As Schäffner 
points out, there are strategies commonly used in translating metaphors such as translating a metaphor into metaphor or sense, or delete all together. The studies commenting on the translations of metaphors are either normative (how to translate metaphors) or descriptive in their approaches (how metaphors are dealt with in actual translations) (Schäffner 2004).

The potential of conflict involved in the transfer of lexis in addressive texts such as those in the media and politics based on the contextual aspects of the source lexeme is a topic already dealth with in TS from the contextual and discursive points of view. These viewpoints of analysis give TS researchers the opportunity to analyze the contexts of utterances with both senders (speakers and translators/interpreters) and receivers of messages (source and target) taken into account along with the aspects of source and target contexts and situations.

For instance, the use of white and black with reference to their original context of use in the US are attributed to the white race (basically the immigrants of AngloSaxon origin and other European immigrants of the continent) and the black race (immigrants of African origin). In a politically correct language, it is always possible to use African-Americans or black community just as any other ethnic community, without any emphasis on the skin colour. In daily use, white race and whiteness is suggestively more advantageous in terms of life standards and privileges although there is supposed to be no discrimination of this sort in today's world as a consequence of all the declarations of human rights and equalities. ${ }^{7}$

Allan and Burridge discuss in length "political correctness" (PC) and the impact of "-ist dysphemisms" in language use as a possible reason for taboo and censoring through euphemisms, because "politically correct" is "ideologically sound" and safe. Yet, the authors continue to say that "[...] PC language is no more a threat to freedom of speech than other types of verbal taboo [...]" (Allan and Burridge 2006: 110). Politically correct language is a result of social conventions such as the need of being accepted in the society through being polite, inoffensive and inclusive and is mainly displayed through euphemistic strategies, which may easily lead to verbal taboos and blocking of free and open linguistic expressions.

Nigger, as one of the examples of analysis taken by the authors under the category of "racist dysphemisms," is introduced as

[r]acist terms are not intrinsically dysphemistic, and can be used without prejudice; for instance 'blacks' is not necessarily any more dysphemistic than 'whites' [...]. Practically all these racist terms can be used without irony in orthophemistic illocutionary acts [...]. (Allan and Burridge 2006: 83-84)

Following an interesting background information about the first occurrence of nigger as a dictionary entry, ${ }^{8}$ the authors refer to the coinage of adjective niggardly from nigger as a politically incorrect neologism which, in 1999, was used by an employee in Washington D.C. Mayoral Office as "being niggardly with funds" to refer to cutbacks as a euphemism of the negative effect of cutback interestingly enough (Allan and Burridge 2006: 102). They also share the results of a survey by BBC, Advertising and Broadcasting Standards Authorities and Independent Television Companies about the swear words on TV programming which is "words of racial abuse are the severest of all taboo words and the reasons for verbal euphemisms/plays nigger being at the top of the severity scale out of 84 swear words in TV programming 
at $53 \%$ by comparison to other swear words such as paki or Jew" (Allan and Burridge 2006: 108).

Allan and Burridge discuss the need and use of politically correct words in all aspects of our lives under a wide variety of euphemistic representations, at times in acronymic forms, from using resale store for second-hand/consignment store; RIF (reduction in force)/downsizing/rightsizing for firing staff; partner for spouse to include all partnered relationships gay, lesbian as well (Allan and Burridge 2006: 96); underdeveloped (1940s), less developed/ lesser developed (1950s), developing (1960s), emerging (more recent) or Third World for poor countries; HIPL for highly indebted poor countries; LD/learning difficulty for mental handicap; hearing impaired for deaf (Allan and Burridge 2006: 100). As for the specific euphemisms developed for black or nigger basically in the US over the years since the tabooing of white and black in the 19th century, Allan and Burridge's following examples are worth mentioning: leg for dark meat; breast for white meat; coffee without milk for black coffee; Darlie Toothpaste for Darkie Toothpaste (Allan and Burridge 2006: 103). A relatively recent example of the use of negro/nigger as a denigrating word in English has been given in the United Kingdom on Channel 4, where the reality show Big Brother House has become the target of a racist remark against the black (African-American) participant of the program. ${ }^{9}$

\section{Black as a political metaphor in Turkish}

Although the vast majority of the country's population is white/Caucasian in racial origin, the concepts of whiteness and blackness are used in Turkish political/ideological language with reference to the privileged vs. the less privileged, or unprivileged groups within the community. Those who are metaphorically called white are the privileged group in comparison to the less privileged resembling it to the disadvantageous status of the black race, as in the source of the metaphor in the US and the rest of the Western World where white and black live together. Linguistically speaking, siyah [black] is neutral and politically correct in Turkish whereas zenci [negro/ nigger] is discriminative in tone, used in opposition to white of everything to refer to a privileged sub-group as an interesting metaphor in political language in Turkey.

The metaphor was started by journalists in the 1990s to differentiate elitist Turks (white Turks) and middle class Turks (black Turks). ${ }^{10}$ White Turks, white students, white Muslims, white anything (white classrooms) or any white group can be used to designate those who seem to have a privilege over the rest. Then, there apparently are black Turks, black students, black Muslims, black classrooms and so on, in contrast with the white of the same group. The semantic operation of expanding the meanings/ names of the two races here has an ideological aspect which results in political incorrectness.

The use of black in Turkish has changed in time from arap, magribi, zenci to $\underline{\text { siyah, }}$ literal equivalent of black, in today's politically correct version. Although the same correctness has given way to a neutral use in English as coloured instead of black, this neutral form had no counterpart in Turkish as renkli [coloured]. Different linguistic forms for black in Turkish include siyah and zenci (also siyahi which literally means blackish in adjective form as a euphemism of black) reflect the society's preferences of use over the historical development of the nation from the Ottoman 
Empire into the Turkish Republic. The word zenci (see note 7) was originally used as a neutral word to refer to the subject of the Ottoman Empire of African origin, basically the enslaved populations working as palace aids and maids. Zenci, literal equivalent of negro (originally used in Spanish), was vulgarized in time gaining an inferior connotation. In today's Turkish siyah [black] is used as the politically correct neutral word since zenci [negro/nigger] still has a discriminative tone to it.

\section{Exemplification: zenci as negro or black}

To exemplify the potential of conflict involved in the interpretation of an explicitly political lexical item in a Turkish source text into English, we will use a Turkish political metaphor from a political interview. The interpreter-mediated interview was held by Deborah Sontag for The New York Times (NYT) on May 11, 2003, Sunday issue. It was undertaken with the Turkish Prime Minister (PM), Recep Tayyip Erdoğan, who is known to give all his foreign speeches and interviews in Turkish. ${ }^{11}$

Although the text of the interview is suitable for analysis as an interpretermediated political interview as a whole, we will limit our discussion with the use of a political metaphor as a lexical item in a political context. Context of use and participants (senders, receivers) of source and target political metaphors will be identified in each case. This will be followed by an attempt of reaching an evaluational decision on the lowness or the highness of their conflict potential as a consequence of the translational decision preferred in each context of use. The critical comments and interpretations that will be based on the analysis could be taken, if anything, as a reflection of the attempt mentioned above.

Having introduced and analyzed the political metaphor zenci [negro/nigger] in the previous section, we will now discuss the contextual implications and translational choices for the metaphor in this specific case. Zenci Türk, as used by the Turkish PM in the interview, stands for the long discriminated conservatives of the country represented by PM Erdoğan's conservative government and Justice and Development Party (AK Parti) as the ruling party since 2002 upon its electional success over the social democrate Republican People's Party (CHP). The target of Erdoğan's words, in this context, seems to be both CHP and the elitist intellectual population of the country.

The interview attracted the attention of the Turkish press to a considerable extent, judging by its coverage in the media (see Appendices 2, 3 and 4). The political metaphor that we focus on in this study seemed to be the major reason why it attracted that much of attention. Journalist Ertuğrul Özkök, for instance, specifically noted the difference in its use in English and Turkish as zenci Türk and black Turk in his daily column $^{12}$ (see Appendix 2 for the English translation of the related extracts from the column). He noted that the Turkish source words by PM Erdoğan (zenci Türk) published in the daily briefs of the General Directorate of Press, Publishing and Information (GDPPI) differed from that (black Turk) in the English text of the interpreter-mediated interview on NYT by Sontag (Appendices 1a and 1b). ${ }^{13}$

The political metaphor was expressed in Turkish and in English as follows: 
(1) a. "Bu ülkede beyaz Türkler ve zenci Türkler ayırımı var. Kardeşiniz zenci Türklere mensuptur."

(Erdoğan, cited in Özkök 14 May 2003 [see note 12]; emphasized by the author)

b. "In this country there is a segregation of Black Turks and White Turks [...] Your brother Tayyip [Erdoğan] belongs to Black Turks."

(Erdoğan, cited in Sontag 11 May 2003 [see note 11]; emphasized by the author)

The above target text displays a translational strategy, on the part of either the interpreter/translator or the editing body of the newspaper (NYT) or even both, of preventing a potential conflict before it occurs. The conflict potential that lies in the violation of the ethical principle of political correctness with the use of negro is eliminated by rendering it as black. The source phrase zenci Türk [negro Turk] is rendered as black Turk through neutral interpretation in the deciphered text of the interview in NYT. The translation of the source phrase as zenci Türk, as is originally uttered by the Turkish PM as negro Turk would create a different effect. Siyah Türk, on the other hand, although being politically correct and definitely low in conflict potential, is not emphatic enough to carry the semantic and political load of zenci, the load apparently intended by the PM in his original choice.

From the perspective of political correctness, this situation prepares grounds for a discussion based on the neutral transfer strategy of NYT (to be politically correct or not to create any conflict) and the potential of conflict involved in the source sentence with the use of an emphatic political metaphor. The contexts of use, the senders and the receivers of the source and target phrases are as follows:

TABLE 1

Source and target phrases in the context of the NYT interview

\begin{tabular}{|l|l|l|l|l|l|l|}
\hline & Phrase & Context of use & Participants & Sender & Receivers & $\begin{array}{l}\text { Conflict } \\
\text { potential }\end{array}$ \\
\hline Source & zenci Türk & $\begin{array}{l}\text { interview } \\
\text { given to NYT }\end{array}$ & $\begin{array}{l}\text { Turkish PM, } \\
\text { American } \\
\text { journalist, } \\
\text { interpreter }\end{array}$ & Turkish PM & $\begin{array}{l}\text { readers of } \\
\text { GDPPI } \\
\text { website in } \\
\text { Turkish }\end{array}$ & high \\
\hline Target & black Turk & $\begin{array}{l}\text { interpretation } \\
\text { of the } \\
\text { interview }\end{array}$ & $\begin{array}{l}\text { Turkish PM, } \\
\text { American } \\
\text { journalist, } \\
\text { interpreter }\end{array}$ & $\begin{array}{l}\text { D. Sontag of } \\
\text { NYT through } \\
\text { interpretation } \\
\text { plus deciphering }\end{array}$ & $\begin{array}{l}\text { readers of } \\
\text { NYT in } \\
\text { English }\end{array}$ & low \\
\hline
\end{tabular}

We might apply the above analysis to siyah Türk as the politically correct source phrase alternative for zenci Türk. We may note that the target alternative which is the same as above literally matches the meaning of the source phrase this time and meets the expectations of political correctness, which lowers the level of conflict potential: 
TABLE 2

Source and target phrases in an hypothetical interview

\begin{tabular}{|l|l|l|l|l|l|l|}
\hline & Phrase & $\begin{array}{l}\text { Context of } \\
\text { use }\end{array}$ & Participants & Sender & Receivers & $\begin{array}{l}\text { Conflict } \\
\text { potential }\end{array}$ \\
\hline $\begin{array}{l}\text { Source, } \\
\text { alternative }\end{array}$ & siyah Türk & $\begin{array}{l}\text { interview } \\
\text { given to NYT } \\
\text { (hypothetical) }\end{array}$ & $\begin{array}{l}\text { Turkish PM, } \\
\text { American } \\
\text { journalist, } \\
\text { interpreter }\end{array}$ & $\begin{array}{l}\text { Turkish PM } \\
\text { (hypothetical) }\end{array}$ & $\begin{array}{l}\text { readers of } \\
\text { GDPPI in } \\
\text { Turkish } \\
\text { (hypothetical) }\end{array}$ & low \\
\hline Target & black Turk & $\begin{array}{l}\text { interpretation } \\
\text { of the } \\
\text { interview }\end{array}$ & $\begin{array}{l}\text { Turkish PM, } \\
\text { American } \\
\text { journalist, } \\
\text { interpreter }\end{array}$ & $\begin{array}{l}\text { DYT through } \\
\text { interpretation } \\
\text { plus } \\
\text { deciphering }\end{array}$ & $\begin{array}{l}\text { NYT in } \\
\text { English }\end{array}$ & low \\
\hline
\end{tabular}

PM Erdoğan might not have intended to be politically correct in his use of the emphatic metaphorical phrase, zenci Türk. Whereas, NYT appeared to be politically correct by transferring the phrase as black Turk in English. This correctness may be the choice of the interpreter or the editing policy of the newspaper. Rendering zenci Türk as negro Turk, on the other hand, as the literal alternative, would sound politically incorrect. It might have also led to a problem of understandability or acceptance considering the limitedness of the international readers' cultural and political background to understand the emphasis in terms of the difference of black and negro in Turkish political discourse. The example, all in all, was powerful enough to show how a speaker's emphasis (potentially viable to conflict) in the source culture's political language could get to be softened up with a euphemistic strategy for political correctness (appropriateness) or even understandability.

\section{Conclusion}

The background and the examples of the present study served the purpose of displaying the conflict potential of political metaphors in political translation as well as text-production with interpreted material. A Turkish example was analyzed as a case with potential of "conflict." Overall topic of political translation and the issues of conflict and ideology involved in the process of translating political texts are, of course, far more sophisticated than the lexical and contextual aspects that were used in the present frame of analysis developed for the purposes of this study. Preliminary observations and the analyses throughout the article led to the following findings with regard to the translation and conflict potential of political metaphors:

1) Political metaphors are lexical items that are frequently used in political texts. The sensitivity of a political metaphor is based on its ideological content in its source political context;

2) Translation of political metaphors are researched under the titles of translation of political texts, written or spoken. Political speeches published or broadcasted through interpretation are valuable as corpus in translation research;

3) A political metaphor such as zenci [negro] may lead to a conflict depending on its context of use. Different target alternatives may reflect different translational strategies. Political correctness seems to call for the strategies of "euphemism" and "neutralisation" which decrease the level of conflict potential; 
4) Translation of a political metaphor can be analyzed with regard to the indicators of its source and target contexts (situation, sender, receiver). The study shows how context-based indicators shape up the ideological value of a source lexical item as well as how this value may be lessened or intensified in the process of interpretation.

Other aspects of the topic could range from interdisciplinary foci discussing the interaction of TS and the fields of politics, sociology, communication and media to the discussion of the issues of conflict and ideology. ${ }^{14}$ All these would result in further research inside TS with respect to the topic of political translation under the following suggested headings:

1) ideological manipulation in political translation in relation to "identity" and "image" of the translator as a social actor;

2) political translation and interpreter-mediated political interviews as examples of this type of translation as processes potentially viable to conflict and ideology issues;

3) interpretation of political speeches or interviews as an object of analysis for the level of ideology or political correctness displayed either through the interpreter's decisions or through the manipulation of the interpreted material in the editing process.

A political metaphor, to sum up, may or may not lead to conflict depending on the translational decision taken in each case. The role of the interpreter in each of these cases would be worth researching as part of the discussion of ideology in translational practice under the general heading of the challenges of translating political texts.

\section{NOTES}

* This article is based on the text of the presentation titled Translation of political texts as a source of conflict: Turkish examples at the Translation and Conflict II Conference, Salford University, Manchester, 16-18 October 2006.

1. Such as Baker 1997, 2006; Schäffner 1997a, 1997b; Hatim and Mason 1997; Kuo and Nakamura 2005.

2. Critical Discourse Analysis takes into account the role of language in social relations of power and ideology in 3 dimensions (description, interpretation, explanation) as an interdisciplinary approach to the study of language (see Fairclough 1989; 1995).

3. In Yaşar Kemal's words (translated from Turkish): "I would never be taken to a court for this article (Der Spiegel). This situation is a result of the manipulations of [...] newspapers and their editors. The alleged translations of my original article in Turkish newspapers are to be blamed for this situation. They published summary translations of the original text by changing and misinterpreting it [...]." Alkan, Nezahat (6 May 1995): Yaşar Kemal’e Teşekkür [Thanks Yaşar Kemal]. Sabah.

4. See, e.g., Ossenova (22 January 2006).

Ossenova, Katerina (22 January 2006): Turkish court drops state slander case against novelist. Jurist. Visited on 15 September 2012, <http://jurist.org/paperchase/2006/01/turkish-court-dropsstate-slander-case.php\#>.

5. Journalist Altan Öymen takes up the issue in his article by quoting Orhan Pamuk's words the day after the press conference in Frankfurt on 22 November 2005 that Öymen attended as a journalist: "Orhan Pamuk's reaction to charges in summary translation: 'I have never used the term genocide, I did not say We killed or Turkey had killed 30.000 Kurds and one million Armenians. I said 30.000 Kurds and one million Armenians were killed in Turkey' [...]. Orhan Pamuk had uttered those two sentences in English. The newspaper had these published through translation into German. Their correct Turkish translation is: 'Burada 30.000 Kürt öldürüldü ve bir milyon da Ermeni' [30.000 Kurds and one million Armenians were killed here] ."

Öymen, Altan (23 November 2005): Orhan Pamuk'un İşi Güçtü [Orhan Pamuk's job was difficult]. Radikal. 
6. The term here refers to the joint tasks of editing and translating in the course of news writing through translation (e.g., Mei 2005).

MEI, Chen-Yei (2005): The target newspaper's ideology as a social factor conditioning the translator's decisions: a news trans-editing perspective, unpublished. Translation and Interpreting as a Social Practice Conference, Graz, 5-7 May 2005.

7. The word zenci (Arabic), zengi (Persian) (negro, meaning Ethiopian at that time; non-literally barbarian and strange) refering to the people of Zanzibar ("Zengibar"/ "Zencibar"). The word negro was used in a negative sense in the 19th century in the Western world until it gained a positive meaning owing to thinkers such as Léopold Sédar Senghor (Senegal), Aimé Césaire (Martinique) and Léon Damas (French Guiana) in the 1930s through the concept of /négritude/.

8. "In 1997, there was a dispute between the publishers of the Merriam-Webster's Collegiate Dictionary (10th edition) and members of the African American Community over the definiton of 'nigger'. The dictionary had indicated the offensive connotations of the term but only after the initial definition of 'nigger' as 'black person'. Those disputing the definition wanted the word listed primarily as a 'slur' with the derogatory sense as part of the principal denotation [...]" (Allan and Burridge 2006:108).

9. Conlan, Tara (7 June 2007): New race row hits Big Brother. The Guardian. Visited on 15 September 2011, <http://www.theguardian.com/media/2007/jun/07/bigbrother.raceintheuk>.

10. See the account of journalists using the metaphor white Turks in the 1990s by Sumer (2003: 79-93). Sumer, Beyza (2003): White vs. black Turks: the civilising process in Turkey. Master thesis, unpublished. Çankaya, Ankara: Middle East Technical University. Visited on 15 December 2012, <http:/etd.lib.metu.edu.tr/upload/1038777/index.pdf>.

11. Sontag, Deborah (11 May 2003): The Erdoğan Experiment. The New York Times.Visited on 15 September 2011, <http://www.nytimes.com/2003/05/11/magazine/the-erdogan-experiment. html?pagewanted $=$ all\&src $=$ pm $>$.

[anonymous] (12 May 2006): Tayyip Erdoğan: Doğu ile Batı arasında bir Kasımpaşalı. [Tayyip Erdoğan: Between East and West] (Translator unknown) NTV-MSBNC. Visited on 15 September 2011, <http://arsiv.ntvmsnbc.com/news/215206.asp >. Note that, in this article, the name of the journalist is spelled Sonntag. See Appendices $1 \mathrm{a}$ and $1 \mathrm{~b}$ for shortened versions of both texts.

12. Özкӧк, Ertuğrul (14 May 2003): "Kardeșiniz bir zenci Türk'tür" ["Your brother is a negro Turk"]. Hürriyet. Visited on 15 September 2011, <http://hurarsiv.hurriyet.com.tr/goster/haber.aspx?id= 146646>. The asterisk and the footnote in the text belongs to Özkök (Appendix 2).

13. The General Directorate of Press, Publishing and Information (Basin-Yayın ve Enformasyon Genel Müdürlüğü) publishes daily briefs for the Press, quoted in Özkök (2003) above (Appendix 2). Visited on 15 September 2012, <http:// www.byegm.gov.tr>.

14. Bulut (2004) discusses the images of translators/interpreters (and translation/interpretation) in public memory as traced by the frequency of occurrence in newspapers and journals with positive and negative images as news items. The political examples of the work include the metaphor dealt with here (p. 35-39).

15. Özcan, Mustafa (17 October 2005): [no title]. Dünya Bülteni. (Translated by the author). Visited on 15 September 2011, <http:www.dunyabulteni.com> (see Appendix 3).

16. Anonymous (12 May 2003): Politika: Erdoğan'ı gözetleniyor [Erdoğan under surveillance]. (Translated by the author) Evrensel. Visited on 31 August 2013, <http://www.evrensel.net/ v1/03/05/12/politika.html> (see Appendix 4).

\section{REFERENCES}

Allan, Keith and Burridge, Kate (2006): Forbidden Words: Taboo and the Censoring of Language. Cambridge: Cambridge University Press.

BAKER, Mona (1997): Non-cognitive constraints and interpreter strategies in political interviews. In: Karl Simms, ed. Translating Sensitive Texts: Linguistic Aspects. Amsterdam: Rodopi. 111-131.

BAKER, Mona (2006): Contextualization in translator and interpreter-mediated events. Journal of Pragmatics. 38(3):321-337.

Bulut, Alev (2004): Gazete ve dergilerden toplumsal belleğe ceviri ve cevirmen [Translation and translators: from newspapers and journals to the social memory]. Hacettepe University Journal of Translation Studies. 14:25-41. 
DAdge, David (2006): The War in Iraq and Why the Media Failed Us. London: Praeger.

FAIRClough, Norman (1989): Language and Power. London: Longman.

FAIrClough, Norman (1995): Critical Discourse Analysis. London: Longman.

Hatim, Basil and Mason, Ian (1997): The Translator as Communicator. London: Routledge.

Kuo, Sai-Hua and Nakamura, Mari (2005): Translation or transformation: A case study of language and ideology in the Taiwanese press. Discourse and Society. 16(3):393-417.

Puurtinen, Tina (1998): Translating linguistic markers of ideology. In: Andrew Chesterman, ed. Translation in Context. Amsterdam/Philadelphia: John Benjamins, 177-186.

RoBin, Maurice (1998): Les mutations politiques du discours à l'est: de L. Brejnev à M. Gorbatchev. Dilbilim [Linguistics]. 1:1-12.

SChäffner, Christina (1997a): Political texts as sensitive texts. In: Karl Simms, ed. Translating Sensitive Texts: Linguistic Aspects. Amsterdam: Rodopi, 132-138.

SChäffner, Christina (1997b): Strategies of translating political texts. In: Anna Trosborg, ed. Text Typology and Translation. Amsterdam/Philadelphia: John Benjamins, 119-143.

SChäffner, Christina (2004): Metaphor and translation. Journal of Pragmatics. 36(7):1253-1269.

Serfaty, Simon (1991): The Media and Foreign Policy. New York: St. Martin's Press.

van Dijk, Teun A. (1988a): News as Discourse. Hillsdale: Erlbaum.

VAN DijK, Teun A. (1988b): News analysis: case studies of international and national news in the press. Hillsdale: Erlbaum.

van Dijk, Teun A. (1998): Ideology: A Multidisciplinary Approach. London: Sage.

\section{APPENDICES}

\section{Appendix 1a}

\section{The Erdoğan Experiment}

[...] during that evening interview last month, at several points while his remarks were being translated, Erdoğan's head bobbed forward [...].

But he is weary of it. "Before anything else, I'm a Muslim," Erdoğan said. "As a Muslim, I try to comply with the requirements of my religion. I have a responsibility to God, who created me, and I try to fulfil that responsibility. But I try now very much to keep this away from my political life, to keep it private." Poker-faced, he exhaled. "A political party cannot have a religion. Only individuals can. Otherwise, you'd be exploiting religion, and religion is so supreme that it cannot be exploited or taken advantage of."

[...] Whereas Erbakan was a flashy dresser and an autocratic figure, Erdoğan styled himself as an authentic representative of the masses. "In this country, there is a segregation of black Turks and white Turks," Erdoğan once said. "Your brother Tayyip belongs to the black Turks."

[...]

Yet from the moment he pronounced himself the "imam" of Istanbul, Erdoğan began both provoking anxieties and recoiling from the fact that he had provoked them. He banned alcohol from municipal establishments, which created concern that he would eliminate alcohol from restaurants too. But he never did. He revived an elaborate project for a mosque complex in the city's heart, then backed off when there were protests. He never clearly allayed secular concerns, keeping them alive instead with comments like: "Democracy is like a streetcar. When you come to your stop, you get off." [...]

Maybe Erdoğan doesn't have the guts or power to push through any serious reforms, least of all on religion. Or maybe Erdoğan, straddling two worlds, is the perfect person to defuse the tensions between secular and religious forces in Turkey.

(Sontag 11 May 2003; emphasized by the author; see note 11) 


\section{Appendix 1b}

Röportaj için karşımda oturan Erdoğan'ın o eski karizmasından hiç bir iz yok. Nerdeyse masaya kapanıp uykuya dalacak. Yorgun halini mazur görmek lazım, iktidardaki ilk ayları oldukça zorlu geçti.

$[\ldots]$

Erdoğan bu konuda temkinli "Ben herşeyden önce" diyor "Müslümanım ve bir Müslüman olarak dinimin emrettiklerini yerine getirmeye çalışırım, beni yaratan Allah'ıma karşı boynumun borcu dinime itaatimdir. Ama bunu siyasi mücadelemin dışında tutmam lazım gelir."

[...] Erbakan'ın İslami-teokratik tarzına karşın Erdoğan ezilmiş kitlelerin "harbi" temsilcisi olarak ortaya çıkar; hangi tarafta olduğu sorulduğunda "kardeşiniz Tayyip, bir 'zenci' Türk’tür” diyerek rengini gösterir. [...]

Kendini “İstanbul'un İmamı” ilan edince kent şoka girdi. Alkol servisinin yasaklanması, Taksim'e cami inşası gibi konularda ülke gerilince "demokrasi bir dolmuş gibidir; vakti gelince inersin" demekle yetindi.

$[\ldots]$

Erdoğan'ın ne din konusunda ne de diğer politik konularda herhangi köklü değişikliğe gidecek cesaret ya da gücü belki de yok. İki dünya arasında kalmış Erdoğan belki de sadece bu nedenle ülkedeki laik ve dini güçler arasındaki gerilimi yumuşatacak en uygun kişi.

(Sontag 12 May 2006; translator unknown; emphasized by the author; see note 13)

\section{Appendix 2}

"Your brother belongs to negro Turks"

The use of "negro" in the title may surprise you. Yet, the statement is not my own, it belongs to Prime Minister Recep Tayyip Erdoğan. There was an interesting biographical essay about Erdoğan published in the Sunday issue of The New York Times [...] in which the Prime Minister says exactly the following: "In this country there is a segregation of White Turks and Negro Turks. Your brother belongs to negro Turks." This portrait was written by journalist Deborah Sonntag upon an interview with him at the Prime Ministry in Ankara [...]. The essay does not make it clear if these words were specifically uttered by the PM at the time of the interview or were taken from an earlier biography. If they were uttered before the elections they may be meaningful in the depiction of his identity. But if he still sees himself as a "negro Turk" sitting in the PM's chair today, then this psychology needs a deeper analysis...

*The newspaper gives it as "Black Turk." Yet the daily report of the Directorate of Press and Information translated the phrase as "Zenci Türk."

(Özkök 14 May 2003; translated and emphasized by the author; the asterisk belongs to Özkök, see note 12)

\section{Appendix 3}

[...] there has been a great deal written on the biographical aspects of Recep Tayyip Erdoğan's life. One of the most interesting of these was a biographical essay published in the NYT by Deborah Sontag, the Jerusalem representative of the newspaper. The title of her essay dated 5 November 2005 was "The Erdoğan Experiment." Later on some journalists referred to this essay. Soli Özel wrote the following, in summary, in this respect: "According to Sontag, Tayip Erdoğan, transformed himself from a religious politician into a secular one through the influences of [...]. In the original text, though, we see statements going far beyond these $[. .$.$] ."$

(Özcan 17 October 2005; translated by the author; see note 15) 


\section{Appendix 4}

In the article by Deborah Sontag Erdoğan's life from his childhood in Kasımpaşa to day has been described and it has been emphasized that "As a devout Muslim with an Islamist past who had nonetheless evolved into a modern, pro-Western democrat, Erdoğan had the potential to set a powerful example for the region. Erdoğan's statements: Prime Minister Erdoğan, in the interview given to the journal, also said the following concerning the suggestion that bureaucrates and the intellectual elite were looking down upon him: "I have faced this all my life... Before anything else, I'm a Muslim... as a Muslim, I try to comply with the requirements of my religion. I have a responsibility to God, who created me, and I try to fulfil that responsibility. But I try now very much to keep this away from my political life, to keep it private... A political party cannot have a religion. Only individuals can...”

(Anonymous 12 May 2003; translated by the author; see note 16) 